Grzegorz Dydkowski - Jozef Gnap

\title{
PREMISES AND LIMITATIONS OF FREE PUBLIC TRANSPORT IMPLEMENTATION
}

For many years issues of the free provision of transport services, including urban public transport, were outside the main trends of transport economics considerations. However, nowadays, the discussion is ongoing related to usefulness and limitations of the free urban public transport implementation. Protection of the city environment, reduction of personal cars traffic, and increased accessibility and mobility in cities are given as premises for such solution introduction. However, assessments of introduced solutions may not necessarily confirm the assumptions made. Financial problems and those in provision of services - characteristic of goods and services provided for free add to that. The paper has undertaken the issue related to premises and limitations related to introduction of the fare free urban public transport in regard to the pursuit of effectiveness in the public management.

Keywords: public transport, free provision, public funds, effectiveness, mobility, policy

\section{Introduction}

In the media, and in professional publications as well, a discussion has been carried out for a few years related to the usefulness and limitations of the free collective public transport implementation. Examples are provided, usually of small cities, which introduced such solutions and benefits, which they plan to achieve due to that. Services of urban collective public transport are free already for many years for selected social groups, these are primarily children (frequently up to 4 years of age), disabled and elderly persons (at the age of more than 70 years). In addition, e.g. councillors, members of parliament, volunteer blood donors, and job seekers are entitled to free rides. A part of entitlements is established by cities, hence the solutions are not uniform. Discussions are related to what extent it would be favourable and justified to give entitlements to all Also residents using the urban public transport in a specific city.

When making a decision on that it is necessary to consider that implementation of a free collective public transport system means reduction of funds inflowing to the urban public transport system. Albeit the ticket revenues cover only a part of costs, for example for five urbanised centres of Poland the ticket revenue consisted in 2017 only $33.7 \%$ of total expenditure and $36.4 \%$ of transport expenditure - based on example of five chosen urbanised centres in Poland, i.e. Warsaw, cities of the central part of Silesian Voivodeship, Poznan, Gdansk, and Szczecin [1], but in nominal terms the obtained funds are not small. At the same time it is difficult to withdraw from such decision, introduction of the free transport is most often a solution for many years.

Obviously the introduction of the free travelling has many supporters, they refer to protection of the city environment, reduction of personal cars traffic in favour of urban public transport; also most generally free availability of goods and services is by nature acceptable, because people do not notice that such services are at a cost, but they do not pay for them directly and that becomes most important for many of them. Because one assigns an entirely different weight to spending own funds - in a thrifty way, but much less to spending the public money. Although such funds originate from taxes, but at the moment of collection they lose their specific owner - obviously this is the public sector - but, as it is shown by many real life examples, the public sector manages resources in a less effective way than the private sector [2-3]. It is also possible to compare economies with state/public ownership of means of production with market economies.

So far, the free urban transport services were not the subject of consideration within the public sector economics [4]. The issues of free provision of transport services for many years were not included in the main area of economic transport problems considerations in Poland - hence there are not many results of studies here. In recent years the issues of urban collective public transport tariffs, in the context of free travelling, are more and more extensively undertaken in the literature on the transport economics. The situation abroad was similar - now it is possible to mention a few dozen valuable papers from the field of „free fare public transport" within recent more than ten years

\footnotetext{
Grzegorz Dydkowski ${ }^{1, *}$, Jozef Gnap ${ }^{2, *}$

${ }^{1}$ Department of Transport, University of Economics in Katowice, Poland and Metropolitan Transport Authority in Katowice (ZTM in Katowice), Poland

${ }^{2}$ Department of Road and Urban Transport, Faculty of Operation and Economics of Transport and Communications, University of Zilina, Slovakia

*E-mail of corresponding author: grzegorz.dydkowski@ue.katowice.pl, jozef.gnap@fpedas.uniza.sk
} 
(See Google Scholar having entered the „free fare public transport" phrase).

This paper raises the issue related to premises and limitations related to introduction of a free urban public transport system; this is a view from the economy point of view and from the perspective of searching for effectiveness in the public management and in public funds spending.

\section{Premises for public financing of urban collective transport}

Most generally, the beginning of gainful urban and regional passenger transport was at the end of the 19th and at the beginning of the 20th century. The urban transport in majority of cities was developing then as a private venture, services were financed by fares paid by passengers. At that time the service prices were regulated by the supply and demand and - as it is the case in such situations and acc. to assumptions - that was ensuring the optimum utilisation of resources. Users of urban public transport were paying fares, which were to cover the costs of used resources and to ensure funds necessary for development. The transport services were provided by private entities, based on general rules, or after obtaining relevant concessions from city authorities [5].

With the passage of time the importance of urban transport for efficient functioning of cities, activation of new districts and hence their development and the city areas growth became to be noticed. So public authorities started to interfere in the urban collective transport services. As a result, the taking over by cities of the ownership (via buying out shares or concessions) of urban collective transport entities was observed, implementation of investment projects by cities, in particular in the field of transport infrastructure, as well as gradual participation in financing the public transport activities.

Development of individual motorisation was a significant factor resulting in the necessity to support urban collective public transport. An increasing number of cars, in particular from mid-20th century in Western European countries, for the urban public transport meant a decline in the passengers number and this next resulted in decreased ticket revenues, which over time could not cover the costs of service provision. Hence the necessity to support urban public transport to maintain the volume of transport by public means of transport. Prices of urban public transport services systematically were becoming one of basic instruments to carry out the transport policy in a given area. Over time, the prices of urban public transport became also instruments to pursue the social policy, to promote employment and to protect health.

Processes similar to those in Western Europe states in the 1950 s and 1960 s were proceeding later on in countries of the former Eastern bloc. In Poland by the end of 1960s the revenues from tickets were still generally covering the cost of public transport services provision. However, the growth of individual motorisation, which started in the 1970s, was systematically causing a growing share of travelling by cars and decreasing movements by the public transport. The necessity to increase the public transport competitiveness against movements by personal cars becomes significant, too [6-7].

In the situation of public financing there is redistribution of funds between users themselves (travelling based on short- and long-term tickets), between various social groups in the municipality, between municipalities (cross-financing between municipalities in a common public transport system). In this context questions are raised with respect to the level of public financing; the subsidy may be small, e.g. of a dozen or so percent, but it can reach as much as $70-80 \%$ of a specific service, like it is now the case in many cities. The higher the public financing, the greater the funds redistribution and the higher burden on public budgets. Moreover, for the entity providing a transport service in practice also the employer changes. In the situation of very high public financing it is the public entity that is, so to speak, the employer and it determines the expectations; in an opposite situation, where the small public financing is assumed, passengers using the services and via fares financing those services provision are the employer.

\section{Is the introduction of free urban public transport justified?}

The discussion and consideration on the free public transport is not something new, only the motives or conditions change, under which this solution implementation is possible. In the past, in socialist states, the free access to many goods or services was perceived as a high stage of the then society development, but this solution was never implemented on a massive scale. Now, attention is drawn to availability of the public transport and its substitution with respect to individual motorisation.

At e introduction of the free public transport benefits are sought in the growing number of rides by the public transport, parallel to giving up individual motorisation. A premise for such statement is the assumption that if some good is provided for free, then the consumption can substantially grow, because people do not need to pay for it. The analysis to what extent introduction of the free public transport results in a change of transport behaviour was carried out by R. Tomanek [8, based on: 9-14]. Declarations related to giving up a personal car at the introduction of free public transport are rather cautious, but also dependent on a number of factors, including the final ticket prices, relationship of the car usage costs, the existing division of transport tasks. It is possible to assume that in Polish cities the number of actual new users will not exceed a level of $13 \%$ [8], where also in this case the caution should be exercised, considering a car-oriented culture of mobility in Poland. Hence under conditions of widespread motorisation, availability and comfort of cars use, no increase of a dozen or a few dozen percent in 
Table 1 Hierarchy of transport postulates among passengers of the Upper-Silesian Industrial Region. Source: [17]

\begin{tabular}{|c|c|c|c|}
\hline Parameter & $\begin{array}{l}\text { Total number } \\
\text { of points }\end{array}$ & Parameter & $\begin{array}{c}\text { Total number of } \\
\text { points }\end{array}$ \\
\hline Punctuality & 8.24 & Travel time & 7.60 \\
\hline Security & 8.24 & Convenience of traveling & 7.44 \\
\hline Directness of connection & 8.12 & External marking of vehicles & 7.21 \\
\hline Reliability & 7.74 & Passenger information & 6.81 \\
\hline Availability of the bus network & 7.73 & Ticket price & 6.57 \\
\hline Frequency of running & 7.66 & Functionality and aesthetics of stops & 6.26 \\
\hline Cleanliness of vehicles & 7.61 & Efficiency of an e-ticket validator & 5.87 \\
\hline
\end{tabular}

Table 2 Attractiveness of free public transport in everyday trip to work. Source: [11]

\begin{tabular}{lccc}
\hline Willingnes to switch & Overall (\%) & Company car (\%) & Private car (\%) \\
\hline Yes, certainly & 9 & 7 & 10 \\
Maybe & 39 & 30 & 42 \\
No, certainly not & 52 & 63 & 48 \\
\hline
\end{tabular}

travelling by the public transport will occur as a result of prices lowering.

Implementation of the fare free urban public transport is to result significantly in a reduced use of cars in the city. That is the objective set by politicians in local governments of cities. However, local politicians in the councillors, office administration and organiser system do not acknowledge the fact that cars are purchased for the purpose that household members would have a better comfort of moving within the city area than that offered by the substitutive urban public transport. The effectiveness of expected benefits from a free urban public transport is low - the car traffic went down by approx. 5\%. Local politicians and their households are the best example in cities with free urban public transport. They still travel by cars, like employees of operators, having free tickets [15].

As the most surveys of transport preferences of big city residents show that the most important transport postulates formulated by them apply to the transport offer, namely direct connections, punctuality, frequency, and accessibility. The expectation of a low cost is for respondents most often a postulate of medium or low importance (Table 1). The results of questionnaire surveys, carried out within the area of Municipal Transport Union of the Upper-Silesian Industrial Region, for the needs of formulating the assumptions of Plan of Sustainable Public Transport Development and results of cyclically performed surveys of Gdynia residents transport preferences and behaviour could be considered an example [16-18].

In addition, the available results of transport preference surveys carried out in cities outside Poland show that the price is not the main factor affecting the choice of means of transport. The results of questionnaire survey of commuters to Brussels, carried out in 2005 by the staff of Vrije Universiteit Brussel can be used as an example. The survey was carried out on a sample of 1276 respondents (526 car users, 740 railway passengers). The carried out survey shows that only $10 \%$ of surveyed persons commuting by an own car declared the willingness to use a free of charge public transport. Instead, $42 \%$ were respondents, who could not clearly declare such willingness and as many as $48 \%$ of surveyed persons were the people, who would certainly not change the means of transport (Table 2). The lack of appropriate connections and an insufficient travel speed were mentioned among the main barriers discouraging the surveyed persons to use the public transport in daily commuting $[11,16]$.

Another argument, presented in favour of the free public transport introduction, is elimination of the mobility exclusion. The free access to services means higher access for persons with low income, which is indisputable and difficult to challenge. However, one should consider whether introduction of the free transport would not limit development of this service sector due to reduction of funds by those originating so far from tickets (in big cities approx. 1/3 of funds). Obviously, the assumption is that funds assigned to the urban public transport should not be decreased, they should be supplemented with a subsidy and benefits obtained in other places, e.g. reduced expenditure on road repairs due to smaller car traffic, but the reality is frequently different from the assumptions made. The deficit in public budgets funds maintaining for years, the necessity to use aid funds and loans for investment projects cause that it is not possible to count on stable and high financing from public funds. Sooner or later, the free of charge public transport will result in an increase in taxes or in giving up other public tasks.

Attention should be also drawn to the fact that in systems of free services, i.e. services not financed directly by the users, but financed from funds available to public entities, hence in general originating from taxes and various charges, there are no mechanisms of flexible adaptation to expectations and - e.g. in the case of growing service volume, so for instance in the urban public transport starting additional connections. This is widely experienced in the case of health care services, where there is a demand 
for specific types of medical services, but there are no possibilities to provide them, because there are no additional public funds that could be allocated to such services. At the same time there is no problem with such services if the user pays. Thus, it is possible to assume that a free urban public transport will result in just such behaviour, i.e. unprofitability or unwillingness to start additional connections, as it is the case of free goods, already mentioned medical services and health protection, but also care services, education or schools.

A low assessment of free goods is also a problem. Providers of goods or of free services know that they are provided free of charge and this decreases their motivation in general to raise and maintain a high quality of services and to develop. Because it is free, actually everybody should be happy that it is. In a similar way the users, at the moment of spending their funds, expect a service consistent with their preferences - also in terms of quality. They do not necessarily express such expectations in the case of free services, frequently a free service is like a social one, of poor quality, addressed just to those, who do not have funds to pay for it. Hence a problem originates, to what extent a fare free urban public transport will make it a poorer quality service and a service perceived as such.

Services of urban public transport are not basic needs, directly related to satisfying hunger, shelter, medical assistance in the case of accidents or illness. In the case of small distances a possibility to walk or to ride a bicycle is a substitute, which does not imply significant expenditure. Obviously, a possibility of changing the place, accessibility to various venues of activity or broadly understood mobility is important and affects the quality of life, however, the usage of urban public transport prices to implement various policies becomes widespread, not only those related to ensuring an efficient transport system.

In modern societies the issues of health protection (concessions for volunteer blood donors), promotion of employment (transport for unemployed), air protection (free transport on smog days), welfare and social functions (pensioners, persons 70+, disabled, children and youth, opposition activists, MPs and senators) are obviously important, but can all that be implemented by means of public transport prices? Is it just? Are the worstoff financed by reducing the prices? Each investment project, improving the living standard of residents, like a stadium, sports arena, swimming pool, kindergarten etc. also requires a capital expenditure, and the users of those investments pay e.g. for an entrance ticket. However, it is very weird that travelling to those services in certain cities is to be for free. There is no such attitude in very wealthy cities worldwide [15]. Free certain municipal services, such as urban public transport, water or electricity consumption, or the use of apartments, are provided in Cuba, Belarus, Venezuela, Turkmenistan, and Tajikistan. Each municipal service for free or paid by a lump sum in those states results in devastation of municipal assets, and - what is the worst - the lack of respect for reasonable consumption of those goods-services [15].
Another motive, raised and supposed to support implementation of free travelling by the urban public transport, is elimination of the transaction costs (cost of sales). However, attention should be drawn to the fact that the ticket sales and inspection systems do not create such a significant cost to decide about introducing a free of charge transport. In general, the tickets inspection itself and financial recovery is financed from the obtained revenue resulting from the imposed additional charges for travelling without a valid ticket. An argument for introduction of the fare free urban public transport, popping up among politicians, is - what can be surprising - an excessive amount of subsidies from the local government budget as against the revenues obtained from tickets sold. The justification is 'very simple' - if subsidies are approx. $80 \%$ of total revenues and the funds from tickets sale only $20 \%$, it is better to give up the tickets distribution (very costly tickets distribution systems have been constructed on a scale not existing in Europe), the tickets inspection and shift to the fare free urban public transport. After all, it is possible to keep the city budget expenditure on public transport on the hitherto level and perhaps even reduce it, through the reduction of expenditures of the entities providing the transport services [15].

Taking into account the quoted results of research, it should be stated that the price is not a basic factor, which will ensure a change of method of movement and hence giving up a car in favour of using the public transport services. Changes in the transport tasks division may be evaluated as a few or a dozen or so percent, but it is necessary to consider the necessity of resolving the problems of financing the current activity and development, as well as the problems accompanying the situation, where goods and services are provided for free.

\section{Practical dimension of free travelling}

In theory, but also in practice, a problem originates to what extent, via public transport prices, functions other than an efficient public transport should be fulfilled. In the price management on a current basis it is possible to encounter applications of various social groups to grant appropriate entitlements to free and concessionary travelling by the public transport and hence to widen the catalogue of hitherto entitlements [19]. Each such application has its social dimension - for the applicants it means appreciation by the public authority of carried out in the past or now activity important for the society, recognition and respect and at the same time some aid having a financial dimension, after all, in the form of reduced expenditure on the public transport. At the same time for public authorities and public transport managers the widening of groups entitled to free or concessionary travelling means a necessity to assign higher funds from the municipality budget on transport financing or to cut costs of urban public transport operations e.g. by reduction of the transport offer. Already now in the urban public 
transport, for example organised in the central part of the Silesian Voivodeship, more than a half of travellers enjoy entitlements to free or concessionary travelling, in addition the prices of season tickets are calculated much below the price, which would result from the number of rides carried out in a given period. As a result, an average payment for one ride is significantly - even three times lower - than the price of a single-travel ticket. Granting entitlements to free or concessionary travelling for the next social groups, at already a significant share of persons holding such entitlements, results frequently in inflating prices of normal tickets, including single-travel tickets. This results in deterioration of price competitiveness of the public transport and ultimately may be one of reasons to give up services of passenger public transport by passengers, who are not entitled to concessionary travels and who use such services occasionally. This additionally increases the deficit of urban public transport services - calculated as the ticket revenue minus costs of services provision.

Prices of urban public transport services are set by municipal local governments. In addition, they are authorised, as it has been previously stated, to determine groups of persons entitled to free and concessionary rides, or to introduce special prices or free rides, for example in relation to the carried out mobility policy or to reduction of the negative effects of transport in the city. The location of powers in the field of local public transport tariff/prices on municipal local government level caused that both prices, and to some extent, groups of persons entitled to concessionary rides, differ between cities. If, for example, the entitlement to concessionary (50\%) rides for children, youth, and pensioners, or free travelling for persons $70+$ does not raise observations and exists widely in Poland, then there are groups, with respect to which various opinions exist, whether they should also be entitled to concessionary or free rides by the urban public transport. In general, this is related to the question, to what extent prices of urban public transport should be used to accomplish policy goals of e.g. health care, unemployment prevention, pro-family policy support, or promotion of education. What is the effectiveness in this case and whether other instruments should be used, for instance providing direct support to persons, who need it.

When considering the system of the fare free transport it is necessary to take into account that the service by the public transport is carried out by municipal public transport systems - first of all bus and tram transport systems (in certain cities also trolleybuses, water trams, and metro in Warsaw) and also by railway carriers. Such systems in big cities and in conurbations operate within a common area, but in Poland there are separate systems of price setting and groups of persons entitled to concessionary and free rides. In addition, the sources and rules of public financing differ - municipality budgets or Voivodeship budgets and the state budget in the case of railway transport. That means that the policy of ticket prices as well as of solutions implementation in the field of concessionary and free rides are not always consistent. Urban systems feature a wider range of persons entitled to concessionary and free rides. The introduction of fare free transport in cities or for specific groups of persons, e.g. children and youth, is related primarily to urban systems. As a result, the modal shifts occur - passengers can use fare free public transport except for rail transport, hence in relations, which are served by both rail and bus/tram transport, it is more favourable to use buses and trams in general. This is not good, because shifts in the transport work occur inconsistently with objectives formulated in transport policies. So disproportions in concessions existing in urban public transport systems and in urban and regional railway transport should be eliminated by the introduction of a consistent and uniform system of concessions and free rides in the urban transport and in the railway transport [20-21].

\section{Summary}

A fare free urban public transport seems as an attractive solution - its introduction allows to obtain a positive assessment and to win passengers favour, it integrates with a general policy of sustainable development of urban transport systems, with increased availability of urban services and actions aimed at residents; mobility improvement. However, the analysis of carried out surveys of residents' transport preferences and behaviour, as well as assessments made in cities, which implemented the fare free public transport services, result in a less positive assessment of this solution. Shifts in the transport work division from individual transport to the public transport are not big and the lack of revenue from sales means that the funds feeding the transport entities will be reduced or the public expenditure will grow. The next issues seem to be postponed in time, will be related to difficulties with ensuring a bigger transport offer and development and introduction of new innovative solutions in this sector. For example, switching to vehicles with lower emission, including electric buses, will be related to significant expenditure on the vehicles and infrastructure, as well as costs will originate related to lower usage of those vehicles - due to the time necessary to charge batteries. Irrespective of that also effects characteristic of goods and services provided for free are likely.

The depriving of revenue on the sales of services may be also related to difficulties in the current financing of urban public transport services. Transport features high energy consumption, materials consumption and a significant share of human factor related costs in the total cost. It is difficult to achieve a growth of productivity, just opposite, the congestion of cities and regulations applicable to drivers working time result in its decrease. Also the labour costs increase as well as burdens incurred in relation to that. In the future it is difficult to assume a decline in fuel or electricity prices, their significant increase should be rather expected. As a result, the growing costs of transport services should be considered and 
this in turn will require ensuring appropriate financing. A component of media, solutions, widespread approval for solutions implementation is visible in the urban public transport, resulting in lowered charges or introduction of free services, unfortunately these are not necessarily solutions, which ensure city effectiveness, competitiveness and development in a longer time horizon.

\section{References}

[1] Urban transport in figures. Data for 12 months of 2017 (in Polish) [online]. Warszawa, 2018. Avaliable from: https://www.igkm.pl/

[2] FREEDMAN, M. I R. Free to choose (in Polish). Sosnowiec: Wydawnictwo Aspekt, 2009. ISBN 978-83-922697-6-2.

[3] SAVAS, E. S. Privatisation. Key for better management (in Polish). Warszawa: Polskie Wydawnictwo Ekonomiczne, 1992.

[4] KAMERSCHEN, D. R, MCKENZIE, R. B., NARDINELLI, C.: Economy (in Polish). Gdansk: Fundacja Gospodarcza NSZZ Solidarnosc, 1999.

[5] DYDKOWSKI, G. Urban transport integration (in Polish). Katowice: Wydawnictwo Uniwersytetu Ekonomicznego w Katowicach, 2009. ISBN 978-83-7246-452-1.

[6] TOMANEK, R. Competitiveness of urban transport (in Polish). Katowice: Wydawnictwo Akademii Ekonomicznej, 2002.

[7] URBANEK, A. Car-oriented mobility culture from the point of view of Polish households' expenditures. In: SUCHANEK, M. (ed) New research trends in transport sustainability and innovation. TranSopot 2017 Conference [online]. Springer International Publishing, 2018. eISBN 978-3-319-74461-2. Avaliable from: https://doi.org/10.1007/978-3-319-74461-2

[8] TOMANEK, R. Effectiveness of free of charge public transport in cities (in Polish). Komunikacja publiczna / Public Transport. 2017, 69(4), p. 18-25. ISSN 1429-5788, eISSN 2543-6570.

[9] BOUSSAUW, K., VANOUTRIVE, T. Transport policy in Belgium: translating sustainability discourses into unsustainable out - comes. Transport Policy [online]. 2017, 53, p. 11-19. ISSN 0967-070X, eISSN 1879-310X. Avaliable from: https://doi.org/10.1016/j.tranpol.2016.08.009

[10] VOLINSKI, J. Implementation and outcomes of fare - free transit systems. A synthesis of transit practice [online]. Washington, D. C.: Transportation Research Board, 2012. ISSN 1073-4880, ISBN 978-0-309-22361-4. Avaliable from: https://doi.org/10.17226/22753

[11] WITTE, A., MACHARIS, C., MAIRESSE, O. How persuasive is 'free' public transport? A survey among commuters in the Brussels Capital Region. Transport Policy [online]. 2008, 15(4), p. 216-224. ISSN 0967-070X, eISSN 1879-310X. Avaliable from: https://doi.org/10.1016/j.tranpol.2008.05.004

[12] MOSES, L. N., WILLIAMSON JR, H. F. Value of time, choice of mode, and the subsidy issue in urban transportation. Journal of Political Economy [online]. 1963, 71(3), p. 247-264. ISSN 0022-3808, eISSN 1537-534X. Available from: https://doi.org/10.1086/258769

[13] CANTERS, R. Hasselt cancels free public transport after 16 years (Belgium) - Eltis [online]. 2014. [Viewed 2017-07-10]. Avaliable from: http://www.eltis.org/di-scover/news/hasselt-cancels-free-public-transport-after-16-years-belgium-0

[14] CATS, O., SUSILO, Y. O., REMAIL, T. The prospects of fare-free public transport: evidence from Tallinn. Transportation [online]. 2017, 44(5), p. 1083-1104. ISSN 0049-4488, eISSN 1572-9435. Avaliable from: https://doi.org/10.1007/s11116-016-9695-5

[15] BAKOWSKI, W. Passive attitude of local politicians in the economic approach to the regulation of residents' movements within an urban area (in Polish). Komunikacja publiczna / Public Transport. 2018, 71(2), p. 34-37. ISSN 1429-5788, eISSN 2543-6570.

[16] URBANEK, A. Will a free of charge urban transport convince passengers to give up personal cars? (in Polish). Komunikacja publiczna / Public Transport. 2017, 69(2), p. 30-35. ISSN 1429-5788, eISSN 2543-6570.

[17] Analysis of results of questionnaire survey carried out within the KZK GOP area (in Polish). Referat Badan i Rozwoju KZK GOP. Katowice, 2012.

[18] Report on 2015 marketing survey (in Polish). Zarzad Komunikacji Miejskiej w Gdyni. Gdynia, 2016.

[19] DYDKOWSKI, G., TOMANEK, R., URBANEK, A. Tariffs and fare collection systems in the urban public transport (in Polish). Katowice: Wydawnictwo Uniwersytetu Ekonomicznego w Katowicach, 2018. ISBN 978-83-7875-441-1.

[20] GNAP, J., KONECNY, V., POLIAK, M.: Demand elasticity of public. Ekonomicky casopis / Journal of Economics. 2006, 54(7), p. 668-684. ISSN 0013-3035.

[21] POLIAK, M., MRNIKOVA, M., JASKIEWICZ, M., JURECKU, R., KACIAKOVA, B. Public transport integration. Communications - Scientific Letters of the University of Zilina [online]. 2017, 19(2), p. 127- 132. ISSN 1335-4205, eISSN 2585-7878. Avaliable from: http://komunikacie.uniza.sk/index.php/communications/article/view/196 